\title{
Teachers' Awareness and Needs of the School-Based Speech-Language Pathologists
}

\author{
Seong Hee Choi ${ }^{a}$, Eun Kyoung Lee ${ }^{b}$ \\ ${ }^{a}$ Department of Audiology \& Speech-Language Pathology, DaeguCatholic University, Gyeongsan, Korea \\ ${ }^{b}$ Department of Speech-Language Pathology, Dongshin University, Naju, Korea
}

\author{
Correspondence: \\ Eun Kyoung Lee, $\mathrm{PhD}$ \\ Department of Speech-Language Pathology, \\ Dongshin University, 67 Donsindae-gil, \\ Naju 58245 , Korea \\ Tel: $+82-61-330-3473$ \\ Fax: +82-61-330-3473 \\ E-mail: eklee00129@gmail.com
}

Received: July 5,2021

Revised: August 20, 2021

Accepted: August 24, 2021
Objectives: Recently, as the population of various students in school classrooms has increased, the need for intervention on various communication problems has been emphasized. This study aims to provide basic data for legislative proposals for speech and language services in schools by investigating teachers' perceptions and demands for establishment of school-based service delevery in speech-language pathology (SLP) in Korea. Methods: Using a Google survey, teachers at kindergarten, elementary, middle and high schools were questioned regarding their perception and demand for school SLP, with a total of 141 teachers responding. Results: The types of communication problems for the students in charge were $37.3 \%$ for multicultural families, $33.3 \%$ for slow learners, and $27 \%$ for children with other communication problems. Among the difficulties in communication among students, social communication skills accounted for $40.6 \%$, followed by literacy with $22.7 \%$, articulation with $16.4 \%$, and vocabulary with $9.4 \%$. More than $80 \%$ of teachers answered that there were students who had difficulty participating in class. Among them, $73.9 \%$ had the most difficulty in understanding the contents of the class, $32.2 \%$ of teachers' instructions, and $17.4 \%$ of class presentations. In addition, it was found that more than half of the teachers interfered with the class or felt a work burden due to students who had difficulty participating in the class. Therefore, for this reason, $96.5 \%$ of teachers thought that having experts to help students would reduce their work burden and help children. Conclusion: Our outcomes demonstrated that teachers recognized the need for professional support at school sites, and mandatory placement of school SLP could provide students and parents with programs that could help improve their academic achievement or social communication skills.

Keywords: Teachers' perception, Needs, School-based speech-language pathology service, School SLP
학교는 또래 아동들이 서로 상호작용하면서 관계를 형성하고, 사 회성 및 학업 수행을 위한 기초 역량을 길러주는 곳이다. 특히, 학령 기 아동들은 학교에서 또래 아동들과 어울리며 다양한 활동에 참 여하면서 자신의 역할을 수행하고 갈등 상황을 해결해 나갈 수 있 는 사회적 의사소통기술을 습득하며 다양한 교과 활동을 통해 일 상생활에서 필요한 지식을 습득하게 된다. 언어는 모든 학습의 기초 가 되는 도구로서 말이나 언어, 의사소통에 어려움이 있거나 상황 에 따른 적절한 언어 사용 기술이 부족한 아동들은 교사, 또래와의 상호작용에 어려움을 겪을 뿐만 아니라 자신감 혹은 자존감 저하,
우울감과 같은 정서적 문제가 발생할 수 있으며, 더 나아가 학업을 수행하는 데도 어려움을 초래하게 된다. 학교는 다양한 환경과 수 준을 가진 학생들이 모인 곳이므로 교실환경에서 말, 언어, 의사소 통의 문제가 있는 학생들을 선별하여 시기 적절한 교육을 제공하거 나 학생 개개인에게 적절한 지도를 통해 정상적인 학교생활을 영위 할 수 있도록 현장 중심의 교육 정책의 전환이 시급하다.

최근 우리나라 학교상황을 살펴보면 학령기 인구는 감소하는 반 면, 그 구성은 다양하게 변하고 있다. 특수교육통계(2020)에 따르면 전체 95,420명의 특수교육대상자 중 유아 6,978명, 초등학생 43,250 
명, 중학생 19,140명, 고등학생 20,655명이었고, 학급별로 특수학급 재학생 52,744명, 일반학급 재학생 16,061 명으로 일반학급 학생의 세 배 이상에 해당하는 특수학급 학생들이 일반학교에서 수업을 받고 있다(Ministry of Education, 2020). 특히, 일반학교 통합교육, 특수학교 및 특수교육지원센터에서 받는 특수교육대상자는 총 95,420 명으로 이 가운데 장애 영역별 특수교육 대상자는 지적장애 $53.1 \%$, 자폐성장애 $14.6 \%$, 의사소통장애 $2.5 \%$ 등 언어장애를 동반 한 장애군의 학생이 66,985 명으로 전체의 $70.2 \%$ 를 차지하고 있다. 이러한 현실 속에서 특수교육대상 아동들은 학교에서 가장 많은 시간을 보내면서 학습 활동과 또래와 생활을 하고 있으나, 현재 특 수교사 및 통합학습교사의 지도에만 의존하고 있어 언어장애나 의 사소통 위험성을 가진 아동들에 대한 교육 지원 체계가 턱없이 부 족한 실정이다.

또한 국제결혼이민자 자녀와 이주노동자 자녀들의 취학이 꾸준 히 증가하면서 교실내 다문화가정 학생이 증가하고 있다. 최근 5년 간 전체 일반학생 수는 감소하는 반면, 다문화가정, 중도입국자 및 북한이탈주민가정 학생은 증가 추세에 있다. 2017년 다문화가정 학 생이 처음으로 10 만명을 넘어섰으며, 2019년은 전년대비 $12.3 \%$ 증가 하였다. 2019년도 다문화가정 학생 현황을 살펴보면, 국내 출생자녀 $78.8 \%$, 중도입국자녀 $6.3 \%$, 외국인가정자녀가 $14.9 \%$ 를 차지하였으 며, 학급별로는 전체 다문화가정 학생의 약 $75.8 \%$ 가 초등학교, 약 $8.4 \%$ 가 고등학교에 재학 중이었다. 현재는 초등학생 구성비가 다른 학교급에 비해 상대적으로 매우 높은 경향을 보이고 있으나 중고등 학생 수도 전년대비 4,171명 증가하는 등 청소년기 다문화가정 학생 도 꾸준히 증가하고 있는 실정이다(Korean Education Statistics Service, 2019). 그러나 다문화가정 학생의 학업중단율은 초등학교 $0.66 \%$, 중학교 $0.73 \%$, 고등학교 $1.62 \%$ 로 학교급이 증가할수록 학업 중단율이 증가하고 있으며, 전체 학생 학업중단율과 거의 맞먹는 수 치이다. 따라서 학교에서 모국어와 문화적 배경의 차이 및 주양육자 의 언어 사용 등으로 인해 학생들이 겪을 학습의 어려움을 보다 정 확히 식별하여, 학생들에게 기본적인 학습권에 대한 권리와 원활한 교우관계 형성을 위한 도움을 제공할 필요가 있다.

이외에도 최근 교실환경은 세계적인 코로나 19 팬더믹의 영향으 로 등교수업 대신 원격수업이 제공됨에 따라 학교 수업 방식이 급격 히 변하고 있으며 이로 인하여 학생들 간 학력 격차가 발생하고 있 다. 학령기 아동의 부모들은 COVID-19 상황으로 인해 학교 수업 방식이 비대면수업으로 전환됨에 따라 자녀의 사회성(43.6\%)과 기 초학력저하(30.5\%)를 가장 우려하는 것으로 나타났다(Seo, 2020). 사회성과 기초학력은 언어를 기반으로 하는데, 한부모 가정이나 조 손가정, 빈곤가정 등 사회적 취약계층은 디지털기기 접근의 한계,
학습공간부족, 학습도우미 부재 등으로 학습권 확보에 어려움을 가지며, 이로 인해 더욱 학력 격차가 심화될 것으로 예상된다.

2013년 교육부에서 실시한 '기초학습 진단 평가'에서 읽기 미달 학생은 $4.55 \%$, 쓰기 미달 학생은 $10.51 \%$ 로 나타났으며, 이러한 학 습부진 학생은 해마다 증가하는 추세이다. 초등학교의 경우, 고학 년 시기에 특수학급으로 오면 많은 학업 실패와 좌절을 경험하였 기 때문에 학습 무기력이 많고, 자리에 앉아 있는 것조차 힘들어 하 는 경우도 많다. 최근 초,중,고 교원 422명을 대상으로 전북 교육정 책에 대한 온라인 설문조사 결과, 교원들의 대다수는 현재 학생들의 기초학력미달 문제에 대해 $58.8 \%$ 가 심각하다고 응답하였다. 또한, 기초학력 향상을 위한 시급한 정책으로 '참학력, '성장평가'등 현행 교육 정책 개선의 검토와 개선이 필요한 것으로 나타났다. 미래교육 역량을 기르기 위해 가장 시급한 교육으로는 '소통능력, 협동심'등 을 길러주는 인성교육(53.1\%), 독서 및 다양한 체험교육(20.4\%)로 나타나 학교현장에서 언어와 의사소통을 교육할 전문가 배치가 매 우 중요함을 보여준다(Jeonbuk Regional Education Research Institute, 2021). 우리나라의 경우, 학교 현장에 이미 상담교사 및 영양 교사, 보건교사가 의무 배치되어 정서 - 심리 및 신체 건강에 대한 학 교지원이 이루어지고 있으나, 기초학력 저하를 책임지고 지도할 전 문인력은 그 필요성에도 불구하고 배제되어 있는 상태이다.

그 밖에도 오늘날 학교 현장에서는 경쟁 위주의 입시 교육과 전 통적이고 권위적인 학교 문화 등으로 인해 의사소통이 중요한 교육 적 요소로 인식되지 못하고 있으며, 의사소통을 위한 교육이 제대 로 이루어지지 않고 있다. 그 결과, 학교 현장에서는 갈등과 충돌이 증가하고, 집단 따돌림과 왕따, 욕설, 폭력, 자살과 같은 비교육적 행위가 빈번히 일어나고 있다. 의사소통능력은 대인관계의 기본이 며 자신을 표현하고 수용하며 공감하는 능력을 키워주며, 긍정적 인 태도로 타인의 생각을 수용하고 원만한 인간 관계를 맺는 가장 기초적인 의사소통능력이다. 이러한 관점에서 사회적 의사소통 교 육은 자라나는 학생들에게 타인과의 원만한 관계를 형성하고 비교 육적인 행위를 올바르게 대처할 수 있는 능력을 키워줄 수 있으며, 학생들의 행동을 변화시킬 수 있다는 점에서 교육적 의의가 매우 크다고 할 수 있다. 따라서, 사회적 의사소통능력은 단편적 프로그 램이나 단기간 교육이나 지도로 이루어지기 어렵고, 어릴 때부터 장기적이고 체계적, 지속적으로 이루어질 필요가 있다. 사회적 의 사소통은 자폐스펙트럼장애, 주의력결핍 과잉행동장애(ADHD), 지적장애, 품행장애 등에 해당되는 학생들뿐만 아니라 다른 동반 장애 없이도 사회적 의사소통장애의 어려움을 겪는 경우도 상당 하다. 사회적 의사소통의 결함은 또래와의 상호작용과 사회성의 문 제로 이어지고, 학업능력에도 어려움을 야기한다. 그러나 이러한 
어려움을 단순 학업부진으로 간과하기 쉽고, 근본적인 사회적 의 사소통능력의 결함을 조기 선별하거나 지원할 수 있는 전문가가 부족한 실정이다. 최근 교육부에서도 디지털 공간에서 비대면 상호 작용이 증가하고 있는 현 시대에서 아동들에게 필요한 역량은 상 대방을 존중하고 배려하면서 소통하는 인성 덕목을 강조하였다 (Ministry of Education, 2021). 인성교육이란, 학교 교육 및 학교 밖 교육에서 인성 가치와 덕목을 내면화하고 의사소통능력, 갈등 해 결 능력을 익히게 하는 것을 핵심 목표로 한다. 따라서, 사회적 의사 소통에 대한 교육은 단순 상담에서 그치는 것이 아니라 전문가를 통한 적극적이고 체계적인 교육이 필요한 시점이다. 하지만, 더불어 살아가는 성품과 역량을 기르는 인성교육 종합계획과 언어 및 다 양한 의사소통문제를 가진 아동들의 다양한 문제들은 교사나 특 수교사중심의 교과 학습만으로는 현장의 다양한 문제를 해결하기 어렵다.

이러한 관점에서, 학교언어재활사(school speech-language pathologist, S-SLP)는 학교환경에서 일반화에 중점을 둔 중재(classroom-based intervention)를 통해 의사소통에 어려움이 있는 학생 들의 언어 및 사회적 의사소통 문제를 해결하는 데 도움을 주는 전 문가를 말한다. 학교언어재활사는 학생들의 의사소통 요구를 반영 하고, 다양한 범위의 의사소통 문제를 조기에 발견하여 진단하고 적절한 중재 프로그램을 개발하여 적용하는 전문인력이다. 미국장 애인교육법(Individuals with Disabilities Education Act, IDEA)에 따르면, 모든 아동에게 일반학급에서 언어치료를 포함한 지원서비 스를 제공해야 한다고 명시되어 있으며, 학교환경에서 언어치료 서 비스를 강조함으로써 학교언어재활사 제도가 시작되었다. 미국에 서는 1950년대부터 “speech teachers" 또는 "speech specialists”라 는 명칭으로 초등학교에 우선 배치되어 학생들의 조음(articulation), 유창성(fluency) 및 음성(voice)장애에 이르기까지 다양한 말-언어장애를 호소하는 학생들의 어려움을 진단하고, 중재를 제 공하는 역할을 해오고 있다. 미국 노동 통계청의 보고에 의하면, 언 어재활사 5 명 중 2 명이 학교에서 일하고 있으며, 언어재활사의 $50 \%$ 이상이 교육 환경에서 일하는 것으로 나타났다(U.S. Bureau of Labor Statistics, BLS, 2020). 이러한 미국의 학교언어재활사 제도는 장 애아동복지법에 따라 장애 아동 및 학생들에게 차별 없는 자연스 러운 환경에서 교육을 받도록 하기 위하여 유치원부터 고등학교에 이르기까지 다양한 학년을 포함한 전 학년에 걸쳐 일하도록 되어 있다. 특히, 언어재활사는 아동의 말언어장애 및 삼킴장애에 대해 더 많은 전문적 지식을 배우며, 아동의 읽기, 쓰기 학습과 말언어장 애에 대한 자격증이 있는 전문가로서 이러한 문제를 다루는데 있 어 더 많은 전문적 지식과 기술을 가지기 때문에 학교에서 나타날
수 있는 다양한 의사소통 문제를 가진 아동들을 선별하고 중재할 수 있는 적임자이다. 우리나라에서도 학교 언어치료 지원은 '장애 인 등에 대한 특수교육법 제정으로 인한 특수교육 관련 서비스의 일환으로 치료지원이 도입되면서 2013년부터 언어재활사에 의한 언어치료가 유·초·중·고 모든 학년으로 확대되었다. 장애인 등에 대 한 특수교육법에 따라 일반학교에서 통합교육을 받는 특수교육대 상자를 지원하기 위하여 일반학교 및 특수교육지원센터에 특수교 육원 및 특수교육관련 서비스 담당 인력을 배치하여 순회 교육을 시행하고 있다. 하지만, 특수교육통계(2020)에 따르면, 순회치료(교 육)에 참여하는 일반학교 특수교육대상자 수는 956명이며, 교사 수는 292명으로 학교현장에 언어재활 전문가가 부족한 상황이다 (Ministry of Education, 2020). 또한, 특수학교나 교육청에서 근무 하고 있는 치료교육교사는 전문적인 치료 분야의 구분 없이 교육 과정에서 제안된 8 가지 영역의 전문 분야를 모두 다루고 있는 실정 이다. 국내에서는 현재 학교언어재활사 중 특수교육지원센터에 소 속되어 있는 경우가 63.5\%로 가장 많았는데(Choi \& Lee, 2016), 언 어재활사가 학교에서 학교로 이동하며 진행되는 현재 순회치료 시 스템으로는 양질의 서비스를 제공하는 데 한계가 있다. 국내 언어 재활사의 순회치료의 실태 연구에 따르면, 학교를 이동함으로써 학 부모와 상담시간을 맞추기 어렵고, 특수교사와 협력적 팀접근에서 도 소통시간이 부족한 것으로 나타났다(Hwang \& Lee, 2016; Yang \& Park, 2016). 또한, 학교 간 거리 및 학생의 수업권 보장으로 인해 순회치료 언어재활사가 치료할 수 있는 시간은 방과후 시간이며, 이로 인해 하루 1-2명 정도의 제한된 치료만이 가능한 실정이다. 이 외에도 언어재활사의 순회치료 시간에 맞춰 특수교육대상자 일정 을 변경하는 상황이 발생하며, 맞벌이 가정이 많아 방과후 치료실 로 부모님이 동반하여 방문할 수 없는 경우가 대부분이었다. 현재 치료지원 대상자의 선정은 영유아, 초, 중, 고, 특수교육대상자 중 진단, 평가결과, 장애 및 발달 특성 등을 기초로 하여 이루어지는 데, 교육적 진단 과정에서 부모의 희망 사항 조사만을 근거로 치료 지원 종류 및 내용이 결정된다. 특히, 지원 영역은 물리치료, 작업치 료, 언어치료, 청능훈련, 심리행동치료, 감각운동지각훈련, 보행훈 련 중 1 인 1 영역에서만 지원이 가능하므로 언어치료 지원이 턱없이 부족한 실정이다. 이러한 순회치료의 제한점을 보완하여 학교에 소 속된 학교언어재활사가 있다면, 특수교육대상자 뿐 아니라 일반학 생들에게 특수교사, 교사와 함께 협력적 팀접근이 가능할 뿐만 아 니라 학부모와도 충분한 상담시간을 통해 가정과도 연계할 수 있 는 부모교육이 가능하므로 양질의 언어재활 서비스를 제공할 수 있을 것이다.

특수교사를 대상으로 한 치료교육 실태 조사에 따르면, 제공되 
는 치료 서비스 중 언어재활에 대한 요구가 가장 높게 나타났다 (National Institute of Special Education, 2006). 특수교육대상자의 의사소통 중재 과정 중 가장 큰 어려움은 발음에 관한 중재였고, 어 휘, 문법과 같이 언어 영역에 관한 언어발달규준에 따른 중재였으 며, 그룹 활동과 발표 상황에서 적절히 말할 수 있는 표현 언어를 위 한 중재, 가정 또는 지역사회에서 주로 사용하는 기능적인 언어를 위한 중재 및 교과 내용의 학습을 위한 중재, 읽기와 쓰기와 같은 중재로 나타났다(Yang \& Park, 2016). 따라서, 본 연구의 목적은 학 교 교사를 대상으로 학생들의 다양성에 따라 학교 현장에서 경험 하는 어려움과 실태를 파악하고 학교언어재활사의 필요성과 인식 및 의무배치에 대한 요구도를 조사하여 국내 학교언어재활사의 제 도적 장치를 위한 기초 자료로 활용하고자 한다.

\section{연구방법}

\section{연구대상}

본 연구는 2021.3.15-3.22까지 유치원, 초등학교, 중고등학교에 근무하는 교사 중 개인정보활용 및 온라인 설문 연구에 동의한 자 를 대상으로 하였다. 147 명이 설문 연구에 참여하였으나, 설문 중 응답이 누락되거나 응답이 완료되지 않은 교사 6명을 제외한 총 141 명을 대상으로 하였다. 연구참여자는 서울경기 34 명, 대구경북 57 명, 경남부산 28 명, 광주전라 22 명으로 총 141 명의 교사가 참여하 였다. 성별은 남자 $12.8 \%$, 여자 $87.2 \%$ 였으며, 연령은 20대(14.2\%), 30 대(24.1\%), 40대(31.9\%), 50대(25.5\%), 60대(4.3\%)였다. 학교급은 유치원(26.2\%), 초등학교 저학년(15.6\%) 초등학교 고학년(15.6\%), 중학교(31.2\%), 고등학교 (11.3\%)였다. 경력은 10년 이상(59.6\%)이 가장 많았으며, 5년 이상 10 년 미만(22.7\%), 3년 이상 5년 미만 (7.1\%), 1년 이상 3 년 미만(7.1\%), 1년 미만(3.5\%)이었다. 재직 중인 학 교 유형은 일반 학급이 $78.6 \%$ 로 가장 많았고, 통합학급( $14.3 \%)$, 특 수학급(7.1\%) 순이었다(Table 1).

\section{설문지 문항 개발 및 제작}

학교기반 언어재활 서비스에 대한 교사 인식 및 요구도를 조사하 기 위하여 학교 언어재활에 관련된 문헌 검토를 실시하였으며, 관 련 사회 기사와 연구 논문(Choi \& Lee, 2016; Hwang \& Lee 2016; Shin, 2020; Yang \& Park, 2016)을 바탕으로 1차 예비 문항을 개발 하였으며, 순회 언어치료를 하고 있는 1 급 언어재활사 2 인 및 언어병 리학과 대학 교수이자 1 급 언어재활사 자격증을 가진 2 인에게 내용 타당도 검증을 받았다. 내용타당도는 각 문항이 학교 현장에서 경 험하는 어려움과 실태를 파악하고 학교언어재활사의 필요성과 인
Table 1. Participants' information

\begin{tabular}{lc}
\hline Classification & Frequency (\%) \\
\hline Age & \\
$20 s^{\prime}$ & $20(14.2)$ \\
$30 s^{\prime}$ & $34(24.1)$ \\
$40 s^{\prime}$ & $45(31.9)$ \\
$50 s^{\prime}$ & $36(25.5)$ \\
60s' & $6(4.3)$ \\
Gender & \\
Males & $18(12.8)$ \\
Females & $123(87.2)$ \\
School level & \\
Kindergarten & $37(26.2)$ \\
Elementary 1-3 Grade & $22(15.6)$ \\
Elementary 4-6 Grade & $22(15.6)$ \\
Middle & $44(31.2)$ \\
High & $16(11.3)$ \\
School type & \\
Normal class & $111(78.6)$ \\
Integrated class & $20(14.3)$ \\
Special class & $10(7.1)$ \\
Career & \\
Less than 1 yr & $54(3.5)$ \\
1-3 yr & $10(7.1)$ \\
$3-5$ yr & $10(7.1)$ \\
M-10 yr & $32(22.7)$ \\
Total & $84.6)$ \\
\hline &
\end{tabular}

식을 살펴보기에 적절한지를 평가하도록 하였으며, 5 점 척도(5점 $=$ 매우 적절하다, $4=$ 적절하다, $3=$ 보통이다, $2=$ 적절하지 않다, $1=$ 아주 적절하지 않다)로 평가하도록 하였다. 3점 미만의 점수를 받 은 문항은 제외하였고, 각 문항에 수정 사항을 적도록 하였다. 내용 타당도 검증을 통해 총 35 문항 중 32 문항을 선정하여 2 차 설문지 를 제작하였다. 제작된 예비 설문지를 대상으로 현직 교사 2 인에게 예비 설문을 실시하였다. 실시 후 문항 중 학교 교사가 이해하기 어 려운 용어는 알기 쉬운 용어로 수정하여 가독성을 높였으며, 반복 되거나 유사한 문항은 삭제하여 최종 문항을 선정하였고, 최종 문 항은 총 30 문항이었다.

설문지는 교사의 기본 정보, 교실 환경에서의 의사소통 문제 관 련 실태(담당 학생의 유형, 주된 의사소통 문제), 학교환경에서 전 문가(학교언어재활사)에 대한 인식과 필요성(교실에서 수업 시간 에 학생과 교사의 어려움 영역 및 전문가 도움의 필요성), 전문가(학 교언어재활사)에 의한 지원 방식에 대한 요구도, 통합학급에 대한 교사 인식과 전문가 도움에 대한 인식, 사회적 의사소통에 대한 교 
Table 2. Contents of questionnaires

\begin{tabular}{|c|c|c|}
\hline Domain & Contents & N. of item \\
\hline Basic information & Age, gender, school level, career & $4(1-4)$ \\
\hline $\begin{array}{l}\text { Status related to communication problems in the classroom } \\
\text { environment }\end{array}$ & $\begin{array}{l}\text { Class type, student types and communication problems types in classroom } \\
\text { environment }\end{array}$ & $3(5-7)$ \\
\hline $\begin{array}{l}\text { Awareness and necessity of experts (school SLP) in the school } \\
\text { environment }\end{array}$ & $\begin{array}{l}\text { Areas of difficulty for students and teachers in classrooms and the need for } \\
\text { expert help }\end{array}$ & $8(8-15)$ \\
\hline Need for the delivery of support by experts (school SLP) & Areas and methods of assistance in curriculum and extra-curricular activities & $9(16-24)$ \\
\hline $\begin{array}{l}\text { Teachers' perception and expert (school SLP) needs for integrated } \\
\text { classes }\end{array}$ & $\begin{array}{l}\text { Teacher perception of integrated classes, teacher awareness of expert help, } \\
\text { and demand for help areas }\end{array}$ & $3(25-27)$ \\
\hline $\begin{array}{l}\text { Teachers' perception and expert (school SLP) needs for social } \\
\text { communication }\end{array}$ & $\begin{array}{l}\text { Teachers' perception of social communication and the need for expert help } \\
\text { and demands on areas }\end{array}$ & $3(28-30)$ \\
\hline
\end{tabular}

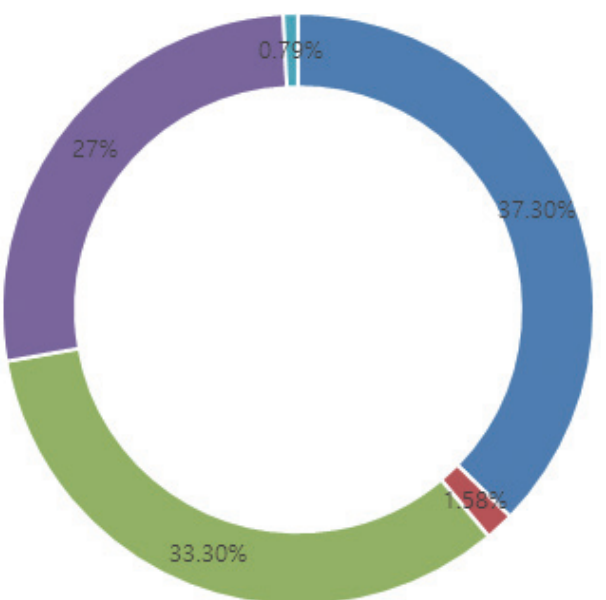

- Multicultural children

- Intermediate immigration student

- Slow learner

- Children with other communication problems

- North Korea defector student

Figure 1. Types of current students in the classroom (unit: \%).

사 인식과 전문가 도움에 대한 인식으로 구성하였다(Table 2). 설문 지 문항 중 9번과 16 번은 복수 응답이 가능하도록 하였다(Appendix 1). 설문지 배포 방식은 google 폼 형식의 설문지를 작성하여 무 기명으로 온라인 설문조사를 실시하였으며, 20-25분 정도 소요되 었다.

\section{결과처리}

수집한 자료는 SPSS (Statistics Package for the Social Science version 21.0)를 이용하여 각 문항을 점수화하여 빈도 분석을 실시 하였다. 학교급별(유치원, 초등학교 저학년, 초등학교 고학년 , 중학 교, 고등학교) 주된 의사소통 문제의 유형의 빈도의 차이를 살펴 보 기 위하여 Fisher의 정확도 검정을 실시하였고, $95 \%$ 수준에서 유의 성을 검증하였다.

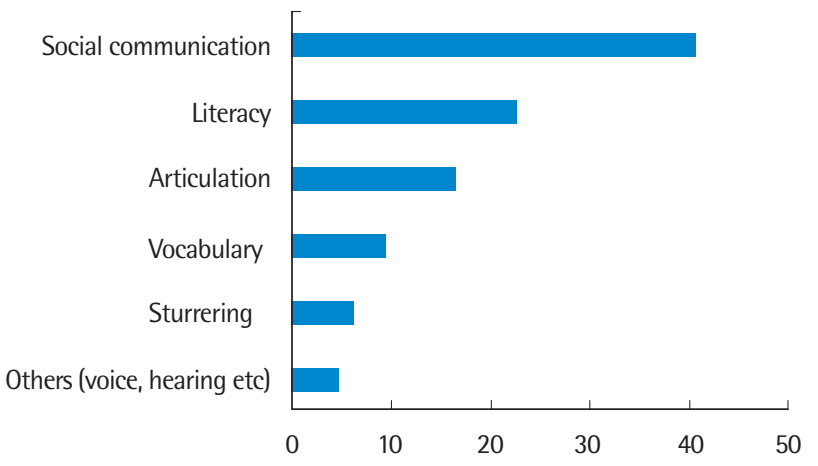

Figure 2. Types of communication difficulties for students in the classroom (unit: \%).

\section{연구결과}

\section{현재 담당 학생의 유형과 주된 의사소통 문제}

교사가 현재 맡고 있는 학생 중 다문화가정 학생은 47 명(37.3\%), 느린 학습자 42 명 $(33.3 \%)$, 기타 의사소통 문제를 가진 학생 34 명 (27\%), 중도입국 학생 2 명 $(1.58 \%)$, 탈북민 학생 1 명 $(0.79 \%)$, 위에 해 당사항이 없는 아동은 15 명(10.63\%)으로 총 141 명 교사 중 126 명 (89.4\%)이 현재 다양한 의사소통 문제를 보이는 학생들을 가르치 고 있는 것으로 나타났다(Figure 1).

최근 2-3년 동안 의사소통 문제를 가진 학생이 있다고 응답한 경 우는 141 명 중 128 명으로 사회적 의사소통기술의 어려움(40.6\%), 문해력(22.7\%), 발음(16.4\%), 어휘력(9.4\%), 말더듬(6.3\%), 음성 및 청각 등 $(4.6 \%)$ 순이었다(Figure 2). 학교급(유치원, 초등학교 저학 년, 초등학교 고학년, 중학교, 고등학교)에 따른 주된 의사소통 문 제의 유형은 유치원의 경우, 총 38 명 중 발음 문제가 16 명(42.1\%)으 로 가장 많았으며, 사회적 의사소통기술이 15 명(39.5\%), 어휘력 3명 (7.9\%) 순이었다. 초등학교 저학년은 총 21 명 응답자 중 사회적의사 소통 기술 6명(28.6\%), 문해력 6명(28.6\%), 발음 4명(19.0\%), 어휘 2 
Table 3. Types of difficulties in communication based on school level

\begin{tabular}{|c|c|c|c|c|c|c|c|c|}
\hline \multirow{2}{*}{ School level } & \multicolumn{8}{|c|}{ Communication difficulties } \\
\hline & $\mathrm{SOC}$ & Literacy & Artic & Voca & Stuttering & Others & None & Total \\
\hline \multicolumn{9}{|l|}{ Kindergarten } \\
\hline Frequency & 15 & 1 & 16 & 3 & 0 & 2 & 1 & 38 \\
\hline WSL (\%) & 39.5 & 2.6 & 42.1 & 7.9 & 0 & 5.3 & 2.6 & 100 \\
\hline WCD (\%) & 28.8 & 3.3 & 72.7 & 25 & 0 & 40 & 7.7 & 27 \\
\hline \multicolumn{9}{|c|}{ Elementary 1-3 grade } \\
\hline Frequency & 6 & 6 & 4 & 2 & 1 & 1 & 1 & 21 \\
\hline WSL (\%) & 28.60 & 28.60 & 19.00 & 9.50 & 4.80 & 4.80 & 4.80 & 100.00 \\
\hline WCD (\%) & 22.70 & 45.50 & 0.00 & 0.00 & 13.60 & 4.50 & 13.60 & 100.00 \\
\hline \multicolumn{9}{|c|}{ Elementary 4-6 grade } \\
\hline Frequency & 5 & 10 & 0 & 0 & 3 & 1 & 3 & 22 \\
\hline WSL $(\%)$ & 22.70 & 45.50 & 0.00 & 0.00 & 13.60 & 4.50 & 13.60 & 100.00 \\
\hline WCD (\%) & 9.60 & 33.30 & 0.00 & 0.00 & 42.90 & 20.00 & 23.10 & 15.60 \\
\hline \multicolumn{9}{|l|}{ Middle } \\
\hline Frequency & 19 & 10 & 1 & 5 & 3 & 1 & 5 & 44 \\
\hline WSL (\%) & 43.20 & 22.70 & 2.30 & 11.40 & 6.80 & 2.30 & 11.40 & 100.00 \\
\hline WCD (\%) & 36.50 & 33.30 & 4.50 & 41.70 & 42.90 & 20.00 & 38.50 & 31.20 \\
\hline \multicolumn{9}{|l|}{ High } \\
\hline Frequency & 7 & 3 & 1 & 2 & 0 & 0 & 3 & 16 \\
\hline WSL (\%) & 43.80 & 18.80 & 6.30 & 12.50 & 0.00 & 0.00 & 18.80 & 100.00 \\
\hline WCD (\%) & 13.50 & 10.00 & 4.50 & 16.70 & 0.00 & 0.00 & 23.10 & 11.30 \\
\hline \multicolumn{9}{|l|}{ Total } \\
\hline Frequency & 52 & 30 & 22 & 12 & 7 & 5 & 13 & 141 \\
\hline WSL (\%) & 36.90 & 21.30 & 15.60 & 8.50 & 5.00 & 3.50 & 9.20 & 100.00 \\
\hline WCD (\%) & 100.00 & 100.00 & 100.00 & 100.00 & 100.00 & 100.00 & 100.00 & 100.00 \\
\hline Total (\%) & 36.90 & 21.30 & 15.60 & 8.50 & 5.00 & 3.50 & 9.20 & 100.00 \\
\hline
\end{tabular}

WSL= within school level; $W C D=$ within communication difficulties; $S O C=$ social communication skill; Artic = articulation; Voca=vocabulary.

명(9.5\%), 말더듬 1 명 $(4.8 \%)$, 음성 1 명 $(4.8 \%)$ 순이었다. 초등학교 고 학년의 경우, 총 22 명 응답자 중 문해력 10 명(45.5\%), 사회적 의사소 통기술 5명(22.7\%), 말더듬 3명(13.6\%), 기타 청각 1명(4.5\%) 순이었 다. 중학교의 경우, 총 44 명 응답자 중 사회적 의사소통기술 19 명 (43.2\%), 문해력 10명(22.7\%) 어휘력 5명(11.4\%), 말더듬 3명(6.8\%), 음성 1 명 $(2.3 \%)$ 이었다. 고등학교의 경우, 총 16 명 응답자 중 사회적 의사소통 기술 7명(43.8\%), 문해력 3명(18.8\%), 어휘력 2명(12.5\%) 순이었다(Table 3, Figure 3).

학교급(유치원, 초등학교 저학년, 초등학교 고학년, 중학교, 고등 학교)에 따른 주된 의사소통 문제의 유형의 빈도의 차이를 살펴보 기 위하여 Fisher의 정확도 검정을 실시한 결과, 학교급별 유의한 차이를 보였다 $(p=.000)$.

\section{교실에서 학생과 교사의 어려움의 영역과 전문가 도움의 필요성}

수업에 참여하는데 어려움이 있는 학생은 141 명 교사 중 $80.1 \%$,
어려워하는 학생이 없다는 $19.9 \%$ 이었다. 수업 중 학생이 어려워하 는 영역으로는 ‘수업 내용의 이해’가 85명(73.9\%)으로 가장 많았고, '교사의 지시따르기'가 37명(32.2\%), '읽기와 쓰기' 35명(30.4\%), '수 업 발표’ 20 명(17.4\%), ‘아이가 활동 자체를 싫어함’ 1 명 $(0.9 \%)$ 으로 나타났다(Figure 4).

한편 교사의 경우, 수업에 참여하는데 어려움이 있는 학생으로 인해 수업 지도의 어려움이 있다고 응답한 경우는 $71.6 \%$, 어려움이 없다고 응답한 경우는 $28.4 \%$ 로 대다수의 교사가 수업 지도의 어려 움이 있는 것으로 파악되었다. 수업에 참여하는데 어려움이 있는 학생으로 인해 다른 학생에게 피해가 있는지 여부에 대해 '예’라고 응답한 경우는 $54.6 \%$, '아니오'라고 응답한 경우는 $45.4 \%$ 였다. 또 한, 교사가 수업에 참여하는데 어려움이 있는 학생을 지도하는 데 업무적 부담을 느끼는지에 대해 ‘예’라고 응답한 경우는 $66.7 \%$, '아 니오'는 $33.3 \%$ 로 업무적 부담을 느끼는 것으로 나타났다. 수업에 참여하는데 어려움이 있는 학생이 있는 경우 해결방법으로는 부모 상담(36.2\%)이 가장 많았으며, 그냥 수업 진행(22.7\%), 전문가 의뢰 


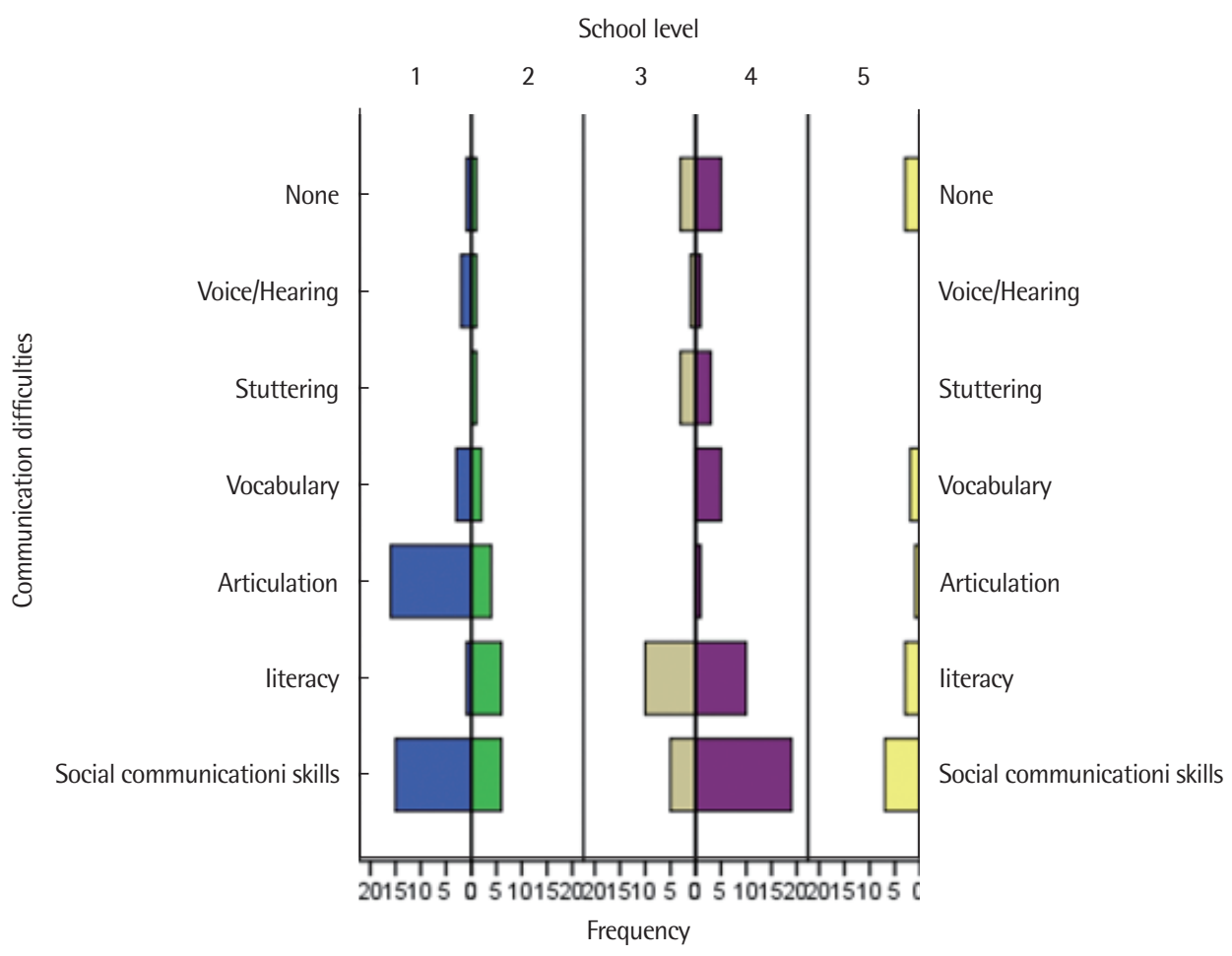

Figure 3. Frequency of types of communication difficulties based on school level.

1 = kindergarten; 2 = elementary school 1-3 grade; 3 = elementary school 4-6 grade; $4=$ middle; 5 =high school.

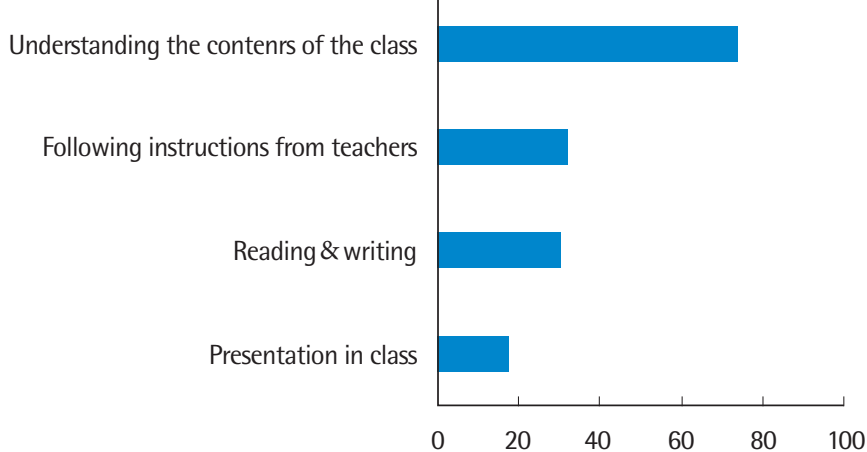

Figure 4. Types of difficulties for class maladaptation students (multiple responses). Unit (\%).

나 요청(15.6\%)순으로 나타났다(Figure 5). 이러한 이유로 인해 수 업에 참여하는데 어려움이 있는 학생을 도와주는 전문가가 있다면 교사의 업무 부담이 감소하는 데 도움이 되는지 여부에 대해 ‘예’라 고 응답한 경우는 141 명 교사 중 130 명(92.2\%)인 대다수가 도움이 되는 것으로 인식하였으며, '아니오’라고 응답한 경우는 11 명(7.8\%) 이었다. 또한, 수업에 참여하는데 어려움이 있는 학생에게 전문가 가 있다면 학생에게 도움이 된다고 응답한 경우는 136명(96.5\%)이 었고, ‘아니오'는 5명(3.5\%)으로 나타나 교사뿐만 아니라 교사와 아 동 모두 학교언어재활사와 같은 전문가의 도움이 필요한 것으로 나

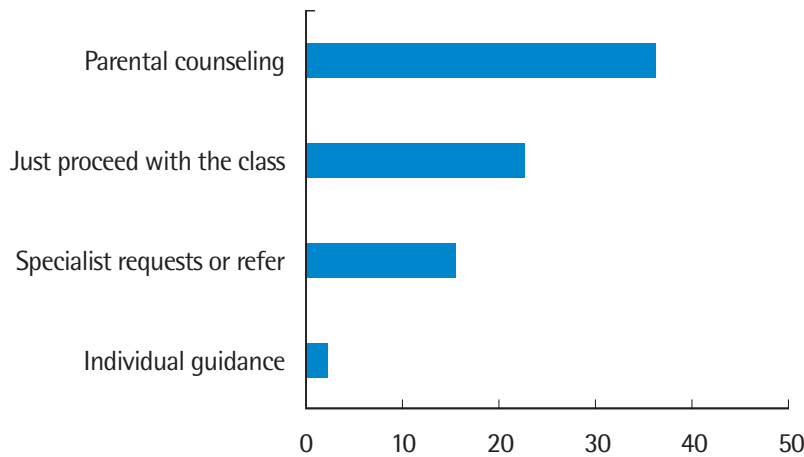

Figure 5. Teachers' guidance methods for students who are maladaptive to class. Unit (\%).

타났다(Figure 6).

\section{전문가 도움의 영역과 지원 형태에 대한 요구}

전문가가 지원해 주기를 바라는 영역으로는 교사 141 명 중 문제 영역에 대한 맞춤형 지원이 $75.9 \%$ 로 가장 많았으며, 교과 기반 지원 (17\%), 부모교육 지원(5.7\%) 순으로 나타났다(Figure 7). 전문가 도 움의 지원 형태는 ‘독립된 공간에서 1:1 지도'(56.7\%)가 가장 많았 고, '교실 참여 협력 교수 체제'가 $41 \%$, '소그룹형태 지도'는 32.6\% 이었으며, ‘보조 교사'가 $0.7 \%$, ‘수업 이후 보충 수업’이 $0.7 \%$, '필요 


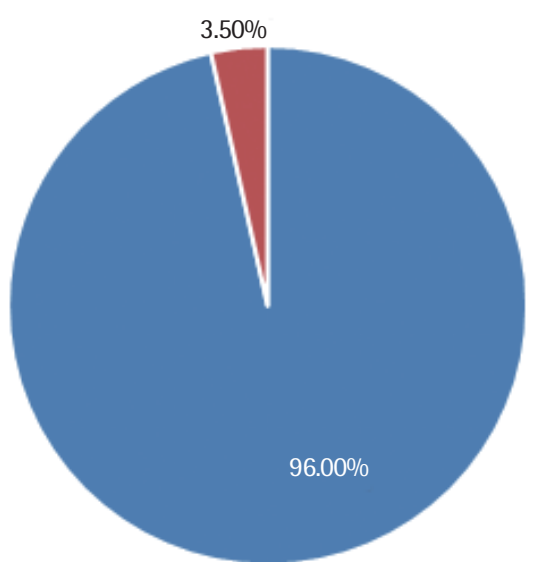

- Experts are needed for students

- No experts needed for students

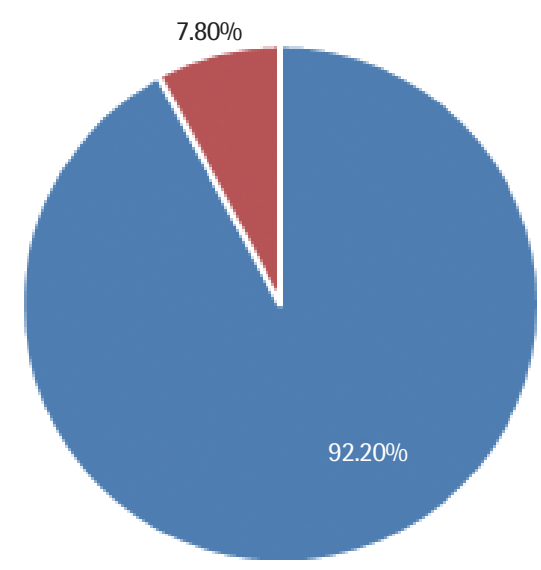

- Experts are needed to reduce the burden on teachers

- No experts are needed to reduce the burden on teachers

Figure 6. Teachers' perception of the need for experts (school SLP) for students and teachers.

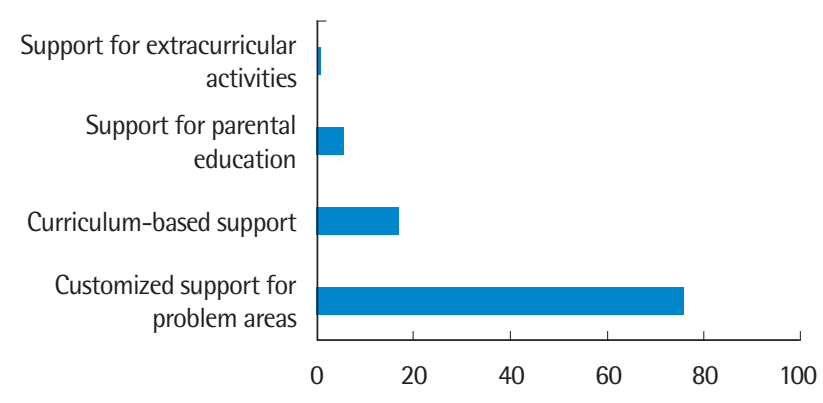

Figure 7. Areas of expert (school SLP) help that teachers demand. Unit(\%).

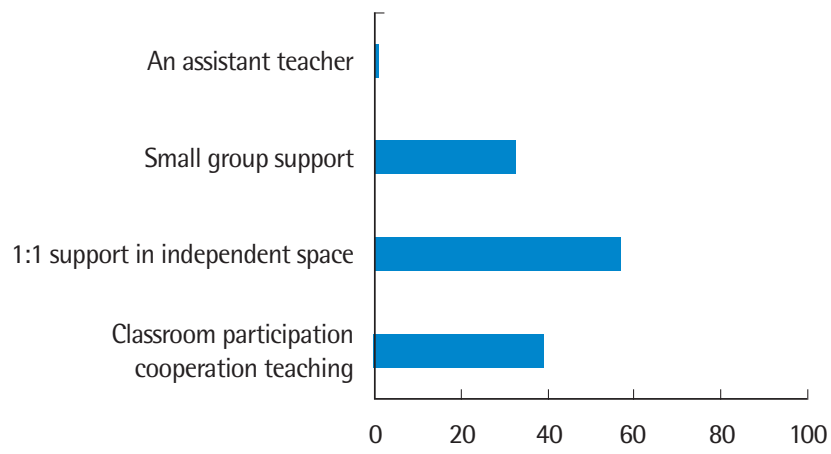

Figure 8. Delivery methods that expert (school SLP) help. Unit (\%).

\section{상황에서 참여'가 $0.7 \%$ 이었다(Figure 8).}

전문가가 있다면 학생에게 어떠한 도움을 줄 수 있을지에 대한 질문에서 학생들의 학습능력 향상이 $34 \%$ 로 가장 많았으며, 사회적 의사소통능력 향상(32.6\%), 학생들의 학교적응능력 향상(26.2\%), 또래 관계 향상(7.2\%) 등으로 나타났다(Figure 9).

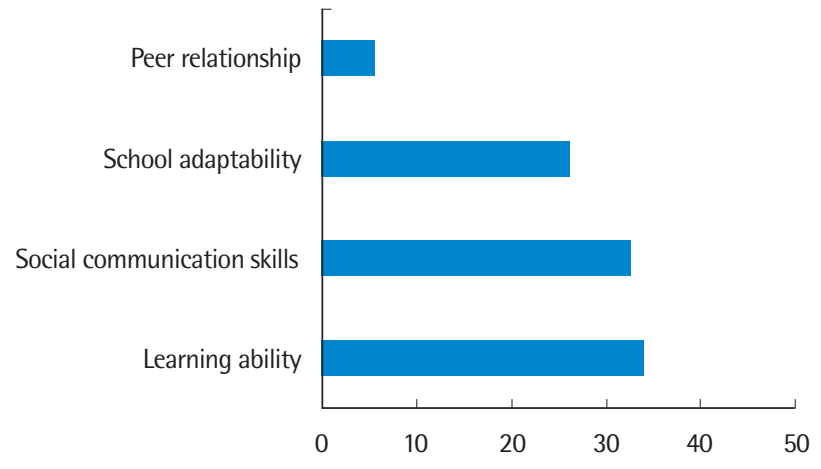

Figure 9. Areas to help with expert deployment. Unit (\%).

\section{전문가의 지원 교과·비교과에 대한 인식과 요구도}

학생들이 교과 수업을 따라가는 데 어려움을 보일 경우, 전문가 의 지원을 받기 원하는 교과목으로는 국어(말하기, 읽기, 쓰기 등) 가 $73.8 \%$ 로 가장 많았으며, 수학(16.3\%), 사회(5\%) 순이었으며, 대 부분의 모든 교과에서 필요하다고 생각하는 경우는 $4.9 \%$ 였다 (Figure 10).

교과목 외에 교과목을 따라가기 위한 인지언어교육의 필요성에 대해 '필요하다'고 응답한 경우는 $94.3 \%$, '필요하지 않다'는 5.7\%로 대부분 필요성을 인식하고 있었다. 수업 집중 향상을 위한 인지언 어교육 중 필요한 영역으로는 문제해결능력이 $48.9 \%$ 로 가장 많았 으며, 덩이글 이해 능력(37.6\%), 청각적 작업기억능력(12.1\%), 기타 컴퓨터나 교재교구 조작 능력( $0.7 \%)$ 으로 나타났다.

언어기반능력(말하기, 읽기, 쓰기, 이해하기 등)이 학생의 학습수 행에 미치는 영향에 대해 '매우 그렇다'는 63.8\%, '그렇다' 27\%, '보 통이다' $7.1 \%$, ‘아니다' $0.7 \%$, ‘매우 아니다' $1.4 \%$ 로 언어기반능력이 아동의 학업수행에 영향을 주는 것으로 인식하였다. 


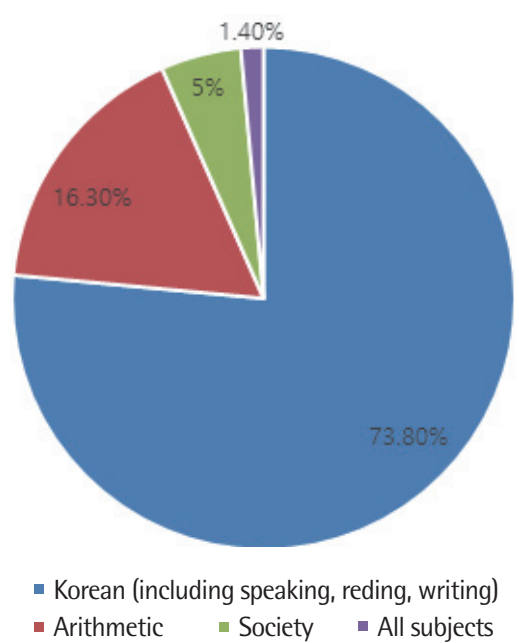

Figure 10. Subjects in need of expert (school SLP) assistance in curriculum.

수업을 따라오기 힘들어하는 학생들이 교과수업과 관련된 언어 능력 중에서 문제를 보이는 영역으로는 문해력(64.5\%)으로 가장 높았으며, 말하기(발표하기 포함) (14.2\%), 청각적 이해력(10.6\%), 위 의 사항 모두(10.7\%)로 나타났다.

교과 활동 외에 다른 학생들과 의사소통이 원활하지 않아 학교 생활 적응에 도움을 주고 싶은 아동을 만난 경험 여부에 대해 '예' 가 114 명(77.3\%), '아니오'는 27명(22.7\%)으로 대부분의 교실 환경 에서 학생들이 의사소통 문제로 인해 학교생활에서 부적응이 나 타나는 것으로 보고하였다. 이러한 경우 교사가 인식하고 있는 도 움이 필요한 영역으로는 사회적 의사소통능력 저하가 $83.3 \%$ 로 가 장 높았으며, 발음 이상(7.9\%), 말더듬(3.5\%), 목소리 이상(0.7\%), 위 의 모두(4.6\%)이었다(Figure 11).

\section{통합학급에 대한 교사 인식과 전문가 도움에 대한 인식}

통합학급 담임을 기꺼이 맡겠는지에 대해 ‘예’라고 응답한 경우 는 72명(54.6\%), '아니오'는 69명(45.5\%)으로 절반에 해당하는 교사 만이 통합학급의 교실 담임에 대해 긍정적으로 인식하는 것으로 나타났다. 통합학급을 맡기 원하지 않는 경우, 교사 69명 중 ‘학생 지도의 어려움'이 $43.5 \%$ 로 가장 큰 원인으로 나타났으며, '교사의 업무 부담 증가' $26.1 \%$, ‘수업 진행의 어려움' $26.1 \%$, '위의 모두에 해 당'하는 경우 $2.8 \%$, ‘전문지식 부족' $1.5 \%$ 이었다.

통합학급에서 특수교육대상자나 다문화 학생들을 위한 교육적 성장을 위해 전문가의 도움이 '필요하다'로 응답한 경우는 교사 141 명 중 138명(97.2\%)이 '예’ 로 응답하였으며, '아니오'는 3명(2.8\%) 에 불과하여 대부분의 교사가 학교언어재활사와 같은 전문가의 도 움을 긍정적으로 인식하는 것으로 나타났다. 전문가의 도움이 필

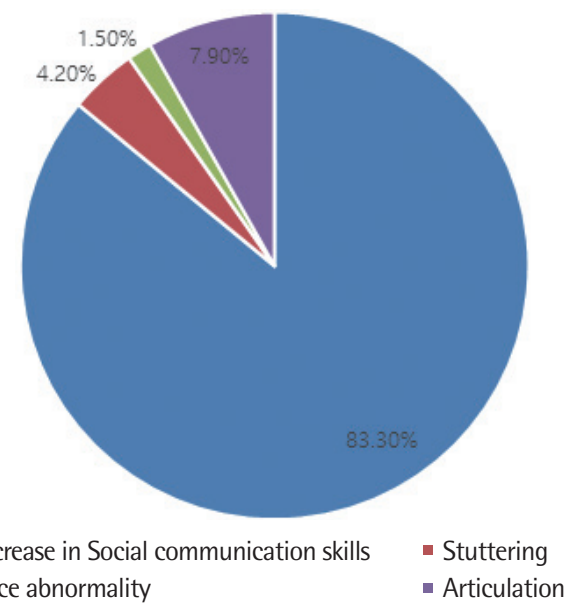

Figure 11. Areas where expert's help is needed for students who are maladjusted to school life due to communication problems

요한 경우 지원을 바라는 도움의 영역은 131 명 중 의사소통중심의 말 - 언어지도가 $39.9 \%$ 로 가장 많았으며, 맞춤형 언어치료지원(35.5\%), 교과과정 연계 언어치료(16.7\%), 수준별 교재교구개발(5.34\%), 수 업 보조(1.53\%) 등이었다.

\section{사회적 의사소통에 대한 교사 인식과 전문가 도움에 대한 인식}

타인을 배려하고 소통하는 능력을 교육하는 것에 대한 필요성에 대해 '필요하다'로 응답한 경우는 141 명 중 140 명(99.3\%), '필요하지 않다'는 1 명 $(0.7 \%)$ 으로 거의 대부분의 교사가 전문가의 도움이 매 우 필요한 것으로 인식하고 있었다.

사회적 의사소통 교육을 담당하는 전문가가 있다면, '학교생활 과 학업에 도움이 된다'고 응답한 경우는 132명(93.6\%), '도움이 되 지 않는다'는 9명(6.4\%)이었다. 이에 대해 사회적 의사소통 교육을 위한 전문가 도움의 지원 방식은 '교과과정을 통한 정기적인 지도' 가 132 명 중 56 명(42.4\%)으로 가장 많았으며, '문제 아동 선별'은 37 명(28\%), '교과외 지도'는 34명(25.8\%), '부모교육을 위한 가정통신 문 배부'는 4 명(3.03\%)이었고, '한국어 교육 외에는 전문가가 아닌 교사 연수나 자기계발을 통한 지도'는 1 명 $(0.8 \%)$ 이었다.

\section{논의 및 결론}

본 연구는 학교기반 언어치료 서비스에 대한 교사들의 인식과 요구도를 살펴보기 위한 것이다. 이를 위해 구글 설문지를 통해 141 명의 교사들로부터 현재 교실에 존재하는 의사소통 문제의 실태를 파악하고 교실에서 학생과 교사의 어려움의 영역과 전문가 도움의 
필요성과 인식에 대해 조사하였다. 그 결과, 담당 학급내에 다문화 가정 학생이 $37.3 \%$ 로 가장 많았으며, 느린 학습자 $33.3 \%$, 기타 의사 소통 문제를 가진 학생이 $27 \%$ 로 나타났다. 이는 우리 사회가 다문 화되어 가고 있음을 보여주며, 교실 내에서 의사소통문제를 보이지 않는 학생은 $10 \%$ 에 불과하였다. 나머지 $90 \%$ 에 육박하는 학생들은 의사소통과 관련된 문제나 위험성을 가지고 있는 것으로 나타났는 데, 이는 단순히 교사중심의 전통적인 교육만으로는 교실의 다양 한 문제를 지도하고, 해결하기에는 어려움이 있을 것으로 여겨진다.

본 연구결과, 최근 2-3년 동안 지도한 학생들이 보이는 의사소통 어려움의 유형은 사회적 의사소통기술이 $40.6 \%$ 로 가장 많았으며, 문해력, 발음, 어휘력, 음성 및 청각 등과 같은 다양한 의사소통 문 제들이 있는 것으로 나타났다. 학교급별(유치원, 초등학교 저학년, 초등학교 고학년, 중학교, 고등학교) 주된 의사소통 문제 유형을 조 사한 결과 통계적으로 유의한 차이를 보였는데, 유치원의 경우는 발음 문제와 사회적 의사소통기술, 어휘력이 주된 문제로 나타났 고, 초등학교 저학년은 사회적 의사소통기술, 문해력, 초등학교 고 학년은 문해력, 사회적 의사소통기술, 말더듬 순으로 나타났다. 중 학교는 사회적 의사소통기술, 문해력, 어휘력이 주된 문제였으며, 고 등학교는 사회적 의사소통기술, 문해력, 어휘력 순이었다(Figure 3).

학년이 올라감에 따라 문해력, 어휘력은 학업 성취를 위한 주된 의사소통 문제였으나, 본 설문 조사 결과, 흥미로운 것은 사회적 의 사소통기술은 모든 학교급에서 나타나는 주된 문제로 학년이 올라 갈수록 사회적 의사소통에 대한 교육이 더 필요한 것으로 나타났 다. Kim, Choi와 Kim, (2006)의 특수 교사를 대상으로 한 학교언어 치료서비스에 대한 인식 조사 연구에서는 언어치료사가 담당할 수 있는 영역으로는 조음 문제(29\%)가 가장 많았고, 유창성(22\%), 구 어 표현 및 이해(17\%)로 응답하였으나, 읽기 장애나 어휘, 문법 등 은 상대적으로 언어치료사가 담당해야 할 부분으로 인식하지 않았 고, 언어 영역(language)보다는 말(speech)영역을 언어치료사가 담 당해야 할 부분이라 인식하고 있었다. 한편, Kim 등(2006)의 설문 연구에서는 특수교사의 $90 \%$ 이상이 최근 2년 이내에 학급에 언어 치료가 필요하다고 생각하는 학생이 있는 것으로 나타났다. 특히, 조음 문제(23\%), 구어 표현의 어려움(17\%), 의사소통 어려움(17\%) 이 많았으며, 언어문제로 발생하는 기타 문제로는 사회성 기술 부 족과 학업 기술의 능력 저하로 응답하였다. 그러나, 이 연구는 초등 특수교사 47 명을 대상으로 조사한 연구로 본 연구의 학교급을 비교 했을 때 초등학교의 특성을 반영한 연구 결과와 유사하였다.

현재 학교현장의 교육 체계가 입시 위주의 학업 성취만을 강조하 는 교육임을 감안할 때, 현장에서 요구하는 가장 절실한 의사소통 교육은 학업 성취를 위한 기초적인 읽기, 쓰기, 말하기 교육 뿐 아니
라 사회적 의사소통에 대한 교육이 시급함을 알 수 있다.

또한, 교사 중 $80 \%$ 이상이 수업에 참여하는데 어려움이 있는 학 생이 있다고 응답하였으며, 이 경우 수업 내용의 이해가 $73.6 \%$ 로 가 장 많았고, 교사의 지시따르기, 수업 발표 등에 어려움이 있다고 하 였다. 수업에 참여하는데 어려움이 있는 학생은 교과 수업과 관련 된 언어능력 중 문해력(읽기, 쓰기) (64.5\%)에서 가장 큰 문제를 보 인다고 인식하고 있었으며, 말하기(발표하기 포함) (14.2\%), 청각적 이해력(10.6\%), 지시따르기(8.5\%)로 나타났다. 또한, 교사들은 수업 집중 향상을 위한 인지언어교육 중에서는 문제해결능력(48.9\%)이 가장 필요하다고 인식하였으며, 덩이글 이해 능력(37.6\%), 청각적 작업기억 능력(12.1\%)으로 언어기반 인지교육의 요구도가 높게 나 타났다. 이러한 현상은 교실 내에서 이루어지는 교과 학습의 대부 분의 기반이 언어와 관련된 듣기, 말하기, 이해하기 등이며 성공적 인 학업 성취를 위해서는 다양한 언어기반의 기초 교육이 병행되거 나 뒷받침되어야 한다는 것을 시사한다. 또한 최근 학생들은 수업 집중 문제 뿐 아니라 타인과의 의사소통 문제에 대해서도 상당히 많은 어려움이 있는 것으로 나타났다. 특히, 교사들이 인식하는 전 문가의 도움이 필요한 영역에는 사회적 의사소통능력의 향상 $83.3 \%$ 로 가장 높게 나타났으며, 교사의 $99.3 \%$ 가 학교에서 타인을 배려하고 소통하는 공감능력을 길러줄 수 있는 사회적 의사소통 교육이 필요하다고 응답하였다. 이러한 사회적 의사소통 교육의 지 원 방식은 교육과정 내 정기적인 지도가 $42.4 \%$ 로 가장 많았다.

교사들의 인식을 살펴본 결과, 교실 내에서 수업에 참여하는데 어려움이 있는 학생으로 인해 실제 수업지도의 어려움, 업무적 부 담, 다른 아동이나 학생에게 피해의 여부 등에 대해 과반수 이상이 '예'라고 응답하였다. 통합학급 담임을 기꺼이 맡겠는지에 대해 절 반에 해당하는 교사만이 통합학급의 교실 담임에 대해 긍정적으 로 인식하는 것으로 나타났다. 통합 학교를 맡기를 원하지 않는 경 우, 그 이유에 대해서는 학생 지도의 어려움이 가장 높았으며, 교사 의 업무 부담 증가와 수업 진행의 어려움, 전문지식 부족으로 나타 났다. 이러한 이유로 인하여 학생을 도와주는 전문가가 있다면 업 무적 부담이 경감될 뿐만 아니라 학생들에게도 도움이 된다고 생 각하는 교사가 $96.5 \%$ 에 달하였다. 이러한 교사들의 인식은 현재 통합교실이 증가하고 있는 교육 현장을 생각할 때, 전문가와 협업 을 통해 보다 세분화된 학생 지도가 필요함을 알 수 있다. 통합학급 에서 특수교육대상자나 다문화가정 학생을 위한 전문가의 도움이 학생들의 교육적 성장을 위해 '필요하다'로 응답한 경우는 교사의 $97.2 \%$ 로 전문가의 역할과 효과를 매우 긍정적으로 인식하고 있는 것으로 나타났다. 전문가의 도움이 필요한 경우 지원을 바라는 도 움의 영역은 의사소통중심의 말 - 언어지도가 가장 많았으며, 맞춤 
형 언어치료지원, 교과과정 연계 언어치료, 부모교육 지원에 대한 요구가 있었으며, 학생 개개인의 수준에 맞는 지원과 부모와의 협 력을 원하는 것으로 나타났다. Kim 등(2006)의 연구에서도 초등 특수교사가 언어치료사에게 원하는 도움의 형태는 학교 내의 직접 적인 언어치료 $59 \%)$ 가 과반수 이상을 차지하였으며, 조음, 유창성, 발성에 관한 직접적인 언어치료의 지원을 요구하였다. 이외에도 표 현언어, 청각장애 학생을 위한 청능 훈련을 직접적인 언어치료의 형 태로 도움 받기를 원하였다. 이외에도 교사가 할 수 있는 언어치료 접근방법에 대한 조언, 어휘 향상을 위한 접근 방법의 조언, 정확한 발음을 유도할 수 있는 중재 방법에 대한 조언과 같이 언어치료에 대한 자문(30\%)을 필요로 하는 것으로 나타났다. 이처럼 특수교사 는 언어나 말과 관련된 전문적인 치료 접근에 대한 정보나 지식이 부족하므로, 학교언어재활사가 배치된다면 이러한 영역에 대하여 전문적 지원과 도움을 줄 수 있을 것이다.

본 연구 결과, 학교언어재활사(언어치료교사)와 같은 전문가가 지원이 된다면, 학생의 학습능력 향상 뿐만 아니라 사회적 의사소 통능력 및 학생들의 학교 적응능력이 향상될 것으로 기대하였다. 학교는 상호작용이 일어나는 가장 자연스러운 환경으로서 언어치 료 서비스를 받는 학생들에게 또래들과 상호작용하며 연령에 적합 한 사회적 의사소통과 인지적 기술을 관찰하고 배우는 기회를 제 공한다(Choi \& Lee, 2016; Elksnin \& Capilouto, 1994). 또한, 학교 환경 언어치료 서비스는 아동이 습득한 다양한 의사소통기술을 자연스럽게 일반화할 수 있기 때문에 언어치료에서 가장 중요한 환 경 중 하나이다(Elksnin \& Capilouto, 1994; Shin, 2020). 따라서, 학 교환경은 언어재활 서비스가 실제적이고 익숙한 환경에서 자연스 럽게 제공되기 때문에 학교생활 뿐만 아니라 가정, 지역사회까지 확장될 수 있다(Park \& Jang, 2003). Kim 등(2006)의 연구에서도 특수교사가 생각하는 학교언어재활사에게 필요한 요건으로는 아 동에 대한 적절한 평가와 진단, 치료와 같은 언어치료의 전문적 지 식과 기술(45\%)을 가장 많이 필요한 요건으로 인식하였으며, 통합 교사와의 지속적인 대화와 협력(35\%), 통합 환경 내에서의 적절한 언어치료 적용(16\%)이었다. 특히, 교사와 공동으로 교실에서 수업 을 한다면, 통합 학급 내에서 언어치료 대상 아동 수준을 이해하고 개별화 교육에 근거한 언어치료 프로그램 개발과 계획, 학교 교육 과정과 학교 생활의 이해로 나타났다. 현재 국내에서도 학교환경에 서 순회 언어치료가 이루어지고 있는데, 학교환경에서 언어치료지 원에 대한 특수교사의 인식을 살펴보면, 특수 교사의 $46 \%$ 가 언어 치료 내용이 전 교과내용에 도움이 되고, 치료를 받기 위해 학교 밖 으로 이동하는 수고를 덜어주었다고 하였다. 하지만, 협력적 팀접근 에 있어서 특수교사와학부모 모두 언어재활사와 소통시간이 부족
하다고 인식하고 있었다. 이와 더불어 특수교사들이 어려워하는 조음 중재에 대한 자문을 얻을 수 있어 언어치료지원의 필요성을 인식하고 있었으며, 치료지원제도가 다시 국가 수준의 교육과정 편 제 및 시간 배당에 재편성되어야 한다고 인식하고 있었다. 최근 15 개 지역 초·중·고 특수학급에 재직 중인 특수교사 66명을 대상으 로 언어치료지원 서비스 실태 조사에 따르면(Hwang \& Lee, 2016), 대상 아동의 장애 유형은 정신지체, 의사소통장애 순이었으며, 대 부분의 아동들이 수용 및 표현언어가 전반적으로 지체되어 있는 경우가 가장 많았으나, 한 학급에 언어치료지원 서비스를 받는 아 동들은 한 학급당 1 명 주 1 회 서비스로 매우 제한적이었다. 따라서 특수학급 조차도 언어치료지원 서비스가 매우 제한적임을 알 수 있다. 언어치료지원 서비스를 이용하고 있는 특수교사 인식을 조사 한 결과, 치료지원 회기, 치료지원 지침, 치료지원 기간 및 교외 방과 후 수업의 차이에 대해 대부분 모르고 있어 특수교사의 언어치료 지원에 대한 정보는 매우 미흡한 것으로 나타났다. 또한, 아동 한 명 당 지원 횟수를 늘리는 치료지원이 필요하다고 인식하고 있었으며, 특수교사들은 아동의 생활연령과 언어연령의 차이가 큰 순서로 치 료지원자를 선정하는 것이 필요하다고 인식하고 있었다. 언어재활 서비스는 시기 적절한 타이밍에 제공되는 것이 중요하므로, 성장 주 기에 따른 다양한 말·언어영역별 조기 진단 및 평가와 이에 따른 시 기 적절한 중재 서비스가 제공되어야 한다.

충남지역의 학교환경의 언어치료 운영 실태에 따르면(Yang \& Park, 2016), 언어치료는 주 2회로 주로 교과시간(국어, 사회 등)에 개별 치료의 형태로 보조인력 없이 실시되고 있었으며, 진단 평가 실태 조사 결과, 학생들은 불명확한 발음으로 인한 의사소통의 어 려움이 있었고, 특수 교사는 언어재활사에게 대상 학생의 현재 수 행 능력에 관한 정보를 제공받고 있는 것으로 나타났다. 치료 전 언 어재활사는 표준화검사를 실시하였고, 언어재활사의 의견에 따라 언어치료 목표가 결정되었고, 언어재활사와 특수교사의 협력적 팀 접근은 매 회기 언어치료 수업 내용을 설명하는 방식으로 이루어 지고 있었다. 본 설문 연구는 일반 교사와 특수교사를 대상으로 실 시되었으며, 설문 참여자는 $92.9 \%$ 가 일반학교 교사로서 이들 중 일 반학급 $78.6 \%$, 통합학급 $14.3 \%$ 에 근무하고 있는 것으로 나타났다. 본 연구의 결과에 의하면 교사들은 특수학교와 특수학급 뿐 아니라 일반학급 내에서도 언어재활사의 도움이 필요한 것으로 나타났다.

미국에서 학교 SLP들은 언어발달장애(development language disorder, DLD) 뿐만 아니라 단순언어발달장애(specific language disorder), 기타 의사소통장애를 가진 아동들을 지원하고 있으며 교실 내에서 교사들과 협력적인 교실 수업모형에 따라 참여하고 있 다. 미국 말-언어-청각 협회(ASHA)에서는 다양한 학교언어재활 서 
비스의 전달 체계를 제시하고 있으며(ASHA, 1996), 언어치료 서비 스 유형 중에는 교실 중심 훈련, 치료실 중심 훈련, 치료 교실 훈련, 지역사회 중심 훈련이 있다. 교실 중심 훈련은 교과과정중심 훈련 으로서 학제 간 훈련을 의미하며, 언어치료 서비스를 학급 교사와 협조를 통해 학생의 교실 상황에서 실시하도록 하는 통합교육 차 원의 훈련을 의미한다. 치료실 중심 훈련은 학생을 교실 밖으로 데 리고 나와서 실시하는 훈련이며, 치료실에서 주로 개별 또는 소그 룹 훈련이 이루어진다. 치료 교실 훈련은 주 장애 치료를 위해 독립 적으로 학급을 운영하며, 훈련이 이루어진다. 치료 교실 훈련에서 는 특수교사, 언어치료사, 보조교사가 학급에서 학생들과 함께 수 업한다. 지역사회 중심 훈련은 학생의 집이나 지역사회에서 훈련을 하는 것으로 치료서비스의 기능에 중점을 둔다. 복합적인 모형은 위의 서비스 유형을 두가지 이상 조합하여 제공하는 것으로 가장 많이 제공되는 언어치료 서비스 유형이다. 이외에도 간접적인 치료 형태인 협력적 자문이 있는데, 이는 학생의 학습 목표능력을 촉진 하기 위해 학급 담임, 특수 교사, 부모 및 가족 등에게 자문 및 상담 을 제공한다. 학교언어재활 서비스 제공 모델은 학교환경이나 여러 요인에 따라 다양한 방식을 채택할 수 있는데, SLP들은 아동 개인 이나 소규모 그룹을 교실 밖으로 이끌어내는 방식(pull out)을 취하 거나, 학급내에서 아동을 지도하는(pull in) 등 특정 기술을 증진할 수 있는 전략을 사용하여 교사에게 모델링 또는 코칭을 제공하여 학생프로그램에 간접적으로 영향을 미치는 서비스를 제공하기도 한다(Suleman et al., 2014). 학교언어재활사와 교사 협력의 교실 기 반 서비스에서는 SLP가 선별된 학생에 대해 지원을 하는 반면, 교 사는 전체 학급을 가르치며, SLP는 음운인식과 같은 SLP의 전문 지식에 속하는 특정 교과 내용을 가르치거나, SLP는 교사와 함께 조별로 공동으로 수업을 하기도 한다(Dohan \& Schulz, 1998; Suleman et al., 2014).

본 연구에서 교사들이 선호하는 전문가 도움의 지원 형태는 복 수선택이 가능하게 하였을 때 '독립된 공간에서 1:1 지도'가 $56.7 \%$ 로 가장 많았고, '교실 참여 협력 교수 체제' $41 \%$, '소그룹형태 지도' $32.6 \%$ 순으로 나타났다. 본 결과에 의하면, 전통적인 언어재활 서 비스 형태인 교실 밖 1:1 지원이 도움이 된다고 인식하고 있는 교사 가 가장 많은 것으로 나타났으나, 교실 참여 협력 교수도 $41 \%$ 에 달 해 교실 내 교사-SLP 협력 교수 전달 방식에 대한 필요성을 인식하 고 있는 것으로 나타났다. 하지만 독립 공간에서 개별 치료만 한다 면, 현재의 교실 밖 언어치료와의 차이점이 없으므로 개별 치료에 서 습득한 기술을 교사 및 또래 학생들과 사용할 수 있도록 일반화 하기 위해서는 학교언어재활사와 교사가 함께 일상 교육 과정 중에 도 적용할 수 있도록 교실 참여 수업이 필요하다. 예컨데, 언어재활
사와 교사가 학생들의 수준에 따라 특수학급이나 통합반에서 함 께 공동 교수 수업을 운영하거나, 일반 학급에서 주 1 회나 월 2 회 정 도의 공동 교수 수업을 진행할 수 있을 것이다. Kim 등(2006)의 연 구에서는 초등 특수 교사들이 개별 언어치료와 간접 치료 병행 (70\%)이 학교 현장에서 가장 적절한 언어치료 서비스 모형으로 응 답하였으며, 직접지원 (10\%), 개별 치료(6\%), 통합적 접근(개별 치료 +간접지원+직접지원)(6\%) 등으로 나타나 서비스 모형에 대한 차이 를 보였다. 본 연구는 유치원부터 고등학교까지 교사 및 일반과 특 수 학교를 포함하였으므로, 학교 형태 및 학교급에 따라 지원 방식 에 대한 인식이 차이를 보일 수 있다. 하지만, Kim 등(2016)의 연구 에서도 간접지원의 경우, 언어치료사로부터 유용한 언어자극의 형 태, 의사소통중재와 관련된 교수 자료 및 아이디어, 아동에게 적절 한 수업, 평가, 과제 등의 수정 방법에 대한 지식과 기술에 대한 정 보를 얻기를 원하였으나, 이러한 형태의 언어치료 서비스가 제공될 경우 대부분의 초등 특수 교사들은 학생에 대한 정확한 평가가 어 렵고, 언어치료사가 제공한 정보들을 교사가 교실에서 적절히 적용 하지 못할 경우 오히려 효과적이지 않거나, 업무 부담이 증가할 것 을 우려하였다. 이러한 관점에서 보았을 때 미국의 경우 학교언어재 활사는 국공립 학교에 의무 배치되어 교사와 함께 협력하며 말, 언 어, 의사소통문제를 보이는 학생들에게 학업 성취에 도달할 수 있 도록 개별 및 공동 교수 수업과 같은 서비스를 제공하고 있다.

즉, 미국의 학교언어재활사는 미국 연방 장애인교육법에 따라 국 공립학교에서 장애 아동에게 다양한 서비스를 제공하며, 공립학교 시스템에서 일자리를 안전하게 보호받을 수 있다. 미국 ASHA에서 는 학교언어재활사에 대한 지침서를 제공하며 학교 언어치료 서비 스 방법에 대한 지속적인 지원을 실시하고 있다. 미국 학교 언어재 활사의 책임과 역할의 범위는 듣기, 말하기, 읽기, 쓰기 및 학습 전 략을 향상시키기 위해 일반 및 특수학급에서 근무하며, 위험군에 속하는 아동을 선별하고 진단하며, 개인 혹은 소그룹 형태의 서비 스를 제공한다. 또한, 말 - 언어장애를 완화하기 위한 전략에 대해 교육전문가와 협력하고 훈련하며, 특정 언어학습 문제에 대한 상담 이 필요할 수 있는 교사의 자원 역할을 하며, 교사와함께 학습자를 위한 커리큘럼에 대해 협력한다. 뿐만 아니라 가정과 학교에서 모두 치료가 이루어지도록 말하기 문제가 있는 학생들의 가족과 함께 협력하고, 상담하며 이에 대한 관리를 위한 문서작업을 시행한다 (ASHA, 2000), 학교언어재활사가 교실 내에서 모델링하고 수정하 는 지침을 제공했을 때 의사소통의 상호작용이 개선됨이 나타났 다. Ebert와 Prelock (1994)의 연구에 따르면, SLP와 함께 공동 언어 교수를 실시한 학급 교사들은 의사소통장애가 학생들의 능력에 미치는 영향을 더 잘 인식하고 학생들에게 더 적절하게 교실 수업 
에 적응하였다고 보고하였다. 또한 교실 교사와 SLP의 공동 중재를 받은 학생들은 듣기, 쓰기, 어휘력 이해에서 통제 집단군에 비해 더 높은 점수를 받은 것으로 나타났다(Farber \& Klein, 1999). Bland 와 Prelock (1996)의 연구에 따르면, 교실 기반 통합 교수와 직접적 인 이끌어내기(pull out) 서비스의 효과에 대한 연구에서 학생들의 발화 명료도가 증가하였으며, 학업 수행력이 증가하였다고 하였다. 최근 교실 내에서 SLP-교사의 공동 교수에 대한 증거기반 학교언어 재활의 효과에 대한 연구에 따르면, 유치원과 초등학교 저학년의 언어발달장애 아동의 어휘 증진에 긍정적인 효과가 있다고 보고되 었다(Murphy et al., 2016). 따라서, 교사-SLP의 협업이나 맞춤형 언 어재활 서비스는 공동의 목표를 달성하기 위해 의사소통장애를 가 진 아동에게 교육적 접근을 공유하며 다양한 의사소통 문제를 가 진 아동에게 성공적인 학업에 도달할 수 있도록 SLP와 교사는 상 호보완하여 역할과 책임을 다할 수 있을 것이다.

본 연구는 전국 단위의 교사를 대상으로 설문 조사를 실시하였 으나, 대상자 수가 많지 않아 추후 연구에서는 이를 확대하여 학교 언어재활사의 역할과 책임에 대한 인식 조사 연구가 확대되어야 할 것이다. 학교언어재활서비스가 성공적으로 정착하기 위해서는 협 업할 교사 뿐 아니라 부모들의 인식과 요구도를 반영한 학교언어재 활 서비스가 되어야 한다. 따라서, 학교 교사의 학교언어재활사에 대한 인식 뿐만 아니라 학부모를 대상으로 학교언어재활사에 대한 필요성과 인식에 대한 연구를 확대할 필요가 있다. 그럼에도 불구 하고 본 연구는 현재 우리나라 교실에 존재하는 교과 및 비교과와 관련된 다양한 의사소통 문제를 파악하고, 학교언어재활사에 대한 학교 현장의 교사들의 인식과 필요성에 대해 살펴본 것에 의의가 있다. 본 연구를 통하여 학교언어재활사의 의무배치는 이러한 급격 한 학교 현장의 변화와 학교 전문가들의 요구를 반영하여 시급히 이루어져야 할 중요한 시대적 과업임을 알 수 있다. 또한, 학교 현장 에서 교사의 교실 수업에 대한 전문 역량과 언어재활사의 전문 역 량이 다르므로 효과적인 교실 모형으로 발전하기 위해서는 교실 안 에서 한 교사만이 교육하는 전통적인 교실 수업의 형태를 벗어나 학교언어재활사가 교실에서 좀 더 실질적인 지원을 할 수 있는 환경 과 제도적 장치가 뒷받침되어야 할 것이다. 또한, 추후에는 일반학 교와 특수학교 및 통합반에서 요구되는 언어치료의 서비스 형태나 모형을 더 자세히 연구할 필요가 있다. 학교언어재활사의 시범 사업 을 통해 학교언어재활 서비스를 제공할 수 있는 공간 제공 뿐 아니 라 교사와 학교언어재활사의 역할과 지원 영역에 대한 범위를 제시 하고 학교언어재활사 모형에 의한 효과를 살펴볼 필요가 있다. 국내 에는 이미 상담교사나 영양교사와 같은 모델이 있으므로 학교환경 에 요구되는 언어교사 모델을 개발하고 이에 대한 증거기반의 언어
재활 서비스 모형을 구축하는 것이 필요하다. 또한, 학교언어재활 서비스를 잘 수행할 수 있는 언어재활사의 역량과 자격 기준도 마 련되어야 한다. 우리나라의 학교기반의 언어재활사 제도를 통해 교 사와학생, 학부모 모두가 행복한 사회가 될 수 있는 밑걸음이 될 수 있기를 기대한다.

\section{REFERENCES}

American Speech-Language-Hearing Association. (1996). Scope of practice in speech-language pathology. ASHA, 38(suppl.16), 35-44.

American Speech-Language-Hearing Association. (2000). Gudelines for the roles and responsibilities of the school-based speech-language pathologist [Guidelines]. Available from www.asha.org/policy/.

Bland, L. E., \& Prelock, P. A. (1996). Effects of collaboration on language performance. Journal of Childrens Communication Development, 17(2), 31-37.

Choi, J. E., \& Lee, Y. (2016). Investigation into the actual condition and job satisfaction of school speech language pathologist. Journal of Speech, Language, and Hearing Disorders, 25(2), 145-160.

Dohan, M., \& Schula, H. (1998). The speech-language pathologist's changing role: collabortion within the classroom. Journal of Chilren's Communicaiton Development, 20(1), 9-18.

Ebert, K. A., \& Prelock, P. A. (1994). Teachers' perceptions of their students with communication disorders: a quantitative and qualitative analysis. Language, Speech, and Hearing Services in School, 38(4),327-41.

Elksnin, L. K., \& Capilouto, G. J. (1994). Speech-language pathologists' perceptions of integrated service delivery in school settings. Language, Speech, and Hearing Services in Schools, 25(4), 258-267.

Farber, J. G., \& Klein, E. R. (1999). Classroom-based assessment of a collaborative intervention program with kindergarten and first grade students. Language, Speech, and Hearing Services in Schools, 30(1), 83-91.

Hwang, W. A., \& Lee, E. K. (2016). Speech therapy support in special educaiton classes in jellanam-do and its perception by special education instrutors. Journal of Speech-Language \&Hearing Disorders, 25(1), 159-171.

Jeonbuk Regional Education Research Institute (2021). An online survey on education policy in Jeollabuk-do.

Kim, S. J., Choi, S. S., \& Kim, J. Y. (2006). Perception of special educators on speech therapy service model in inlusive school contexts. Korean Journal of Communication Disorders, 11(1), 121-139.

Korean Education Statistics Service. (2019). Statistical yearbook of education. Retrieved from https://kess.kedi.re.kr. 
Ministry of Education. (2020). Statistical yearbook of special education. Sejeong: Ministry of Education.

Ministry of Education. (2021). The 2nd Comprehensive Plan for Personality Education. Sejong: Ministry of Education.

Murphy, A., Franklin, S., Breen, A., Hanlon, M., McNamara, A., Bogue, A., \& James, E. (2016). A whole class teaching approach to improve the vocabulary skills of adolescents attending mainstream secondary school. in areas of socioeconomic disadvantage. Child Language Teaching and Therapy, 33(2), 129-144.

National Institute of Special Education. (2006). A Study on the status and improvement of treatment education. Retrieved from http://www.nise.go.kr/.

Seo, M. O. (2020). The study of graduate students perceptions in the graduate school of education that related the case of online class in the corona 19 Pandemic. Journal of Learner-Centered Curriculum and Instruction.
21(2), 561-582.

Suleman, S., McFarlane, L., Pollock, K., Schneider, P., Leroy, C., \& Skoczylas, M. (2014). Collaboration: mo than 'working together': an exploratory study to determine effect of interprofessional education on awareness and application of models of specialized service delivery by student speechlanguage pathologists and teachers. Canadian Journal of Speech Language Pathology and Audiology, 37(4), 298-307.

United States Department of Labor. (2020). U. S. Bureau of Labor Statistics 2020.

Yang, J. H., \& Park, S. J. (2016). A Survey of the actual condition and awareness of special education teacher about speech therapy in school setting: focused on Chungnam region. Journal of Special education \& Rehabilitation Science, 55(3), 537-557. 
Appendix 1. Online survey

\section{〈학교언어재활사의 필요성과 인식 조사〉}

안녕하세요?

늘 학생들을 가르치시고 지도하시는 스승님의 은혜에 감사드립니다.

본 설문지 연구는 학교언어재활사 제도적 장치와 관련하여 선생님들께 학교언어재활사의 필요성과 인식에 대해 조사하려고 합니다.

최근 학령기 인구는 감소하였으나 다문화가정학생, 중도입국 및 북한이탈주민가정학생 증가와 코로나19 이후 느린 학습자의 증가, 일반학교에서 특수교육대상자 의 통합학급의 증가로 학교 인구가 다양해졌습니다.

언어는 학습의 주된 도구이고 의사소통은 타인과 소통하고 관계를 형성하는데 매우 중요합니다. 언어와 의사소통교육은 모든 교육과 학습의 기초가 되는 뿌리 교 육입니다.

본 설문연구는 최근 급격하게 변하고 있는 학교 현장에서 학생들의 다양성에 따라 선생님들께서 겪는 경험과 실태 및 인식을 조사하고자 합니다.

선생님들의 소중한 의견과 답변이 큰 도움이 될 것입니다.

다시 한번 소중한 답변 주셔서 감사드립니다.

https://forms.gle/bRsTsVdeQdNXMmtd8

1. 선생님의 성별을 표시해주십시오.

1) 남자 2) 여자

2. 선생님의 연령대를 표시해주십시오.
1) 20 대
2) 30 대
3) 40 대
4) 50 대
5) 60 대

3. 선생님의 학교급을 표시해주십시오.

1) 유치원 2) 초등학교 저학년 3 3) 초등학교 고학년

4) 중학교 5) 고등학교

4. 선생님의 경력기간을 표시해주십시오.

1) 1년 미만 2) 1년 이상-3년 미만 3) 3년 이상-5년 미만

4) 5년 이상-10년 미만 5) 10 년 이상

5. 선생님께서 맡은 학급은 어떤 형태입니까?

$\begin{array}{lll}\text { 1) 일반학급 } & \text { 2) 통합학급 } & 3 \text { ) 기타 }\end{array}$

6. 현재 맡으신 아동(학생) 중 아래 해당하는 아동이 있습니까?

1) 다문화가정학생 2) 중도입국학생 3) 북한이탈주민가정학생

4) 느린학습자 5) 기타 의사소통 문제를 가진 학생 6) 없음

7. 최근 2-3년 동안 의사소통 문제를 가진 학생이 있다면 다음 어디에 해당합니까?

1) 발음 2) 어휘력 3) 문해력 4) 말더듬

5) 사회적 의사소통 $\quad 6)$ 목소리 이상 7$)$ 기타

8. 선생님의 학급에 수업을 따라가기 어려워하는 아동이 있습니까?

1) 예 2) 아니오

9. 1)번이라면 어느 부분에서 어려움이 있었습니까? (중복 체크 가능)

1) 수업 내용의 이해 2) 수업 발표 3) 교사의 지시따르기 4) 읽기와 쓰기 5) 기타 
10. 선생님의 학급에 수업을 따라가기 어려워하는 학생으로 인해 수업 지도의 어려움이 있었습니까?

1) 예 2) 아니오

11. 수업을 따라가기 어려워하는 학생으로 인해 다른 아동에게 피해가 됩니까?

1) 예 2) 아니오

12. 선생님의 학급에 수업을 따라가기 어려워하는 학생을 지도하는 데 업무적 부담을 느끼십니까?

1) 예 2) 아니오

13. 수업을 따라오기 어려운 학생이 있었다면 어떻게 지도하셨습니까?

1) 전문가 의뢰나 요청 $\quad$ 2) 부모 상담 $\quad 3$ ) 그냥 수업 진행 $\quad 4)$ 기타

14. 수업시간에 수업을 따라가기 어려워하는 학생을 도와주는 전문가가 있다면 교사의 업무 부담이 감소되는 데 도움이 된다고 생각하십니까?

1) 예 2) 아니오

15. 수업시간에 수업을 따라가기 어려워하는 학생들에게 전문가가 있다면 이 아동들에게 도움이 된다고 생각하십니까?

1) 예 2) 아니오

16. 전문가가 있다면 도움의 형태는 어떠한 방식으로 이루어지는 것이 적절하다고 생각하십니까? (중복 체크 가능)

$\begin{array}{llll}\text { 1) 교실 참여 협력 교수 체제 } & \text { 2) 독립된 공간에서 1:1 수업 } & \text { 3) 소그룹 형태 지도 } & \text { 4) 기타 }\end{array}$

17. 전문가가 있다면 도움의 내용은 어떠한 것을 지원하는 것이 바람직하다고 생각하십니까?

$\begin{array}{lll}\text { 1) 교과 기반 지원 } & \text { 2) 문제 영역에 대한 맞춤형 지원 } & 3 \text { 3) 부모 교육 지원 }\end{array}$

18. 전문가가 있다면 어떤 도움이 되겠습니까?

1) 학생의 학습 능력 향상 $\quad$ 2) 학생의 학교 적응 능력 향상 $\quad 3$ ) 또래 관계 향상

4) 사회적 의사소통능력 향상 5) 기타

19. 학생이 교과수업을 따라가는데 어려움을 보인다면, 특히 어느 교과목의 도움이 필요하다고 생각하십니까?

1) 국어(말하기, 읽기, 쓰기 등 포함) 2 2) 산수(수학) 3 3) 사회 4 4) 기타

20. 교과목 외에 교과목을 따라가기 위한 인지언어교육지도가 필요하다고 생각하십니까?

1) 예 2) 아니오

21. 수업 집중 향상을 위한 인지언어교육 중 어느 것이 필요하다고 생각하십니까?

1) 청각적 작업기억 능력 $\quad$ 2) 덩이글 이해능력 3 3) 문제해결능력

4) 컴퓨터나 교재교구 조작능력 5) 기타

22. 언어기반 능력(말하기, 읽기, 쓰기, 이해하기 등)이 학생의 학습 수행에 영향을 미친다고 생각하십니까?

1) 매우 아니다 2) 아니다 3) 보통이다 4) 그렇다 5) 매우 그렇다

23. 수업을 따라오기 힘들어하는 학생들은 교과수업과 관련된 언어능력 중 다음 어느 능력에 문제를 보인다고 생각하십니까?
1) 말하기(발표하기 포함)
2) 문해력(읽기, 쓰기)
3) 지시따르기
4) 청각적 이해력
5) 기타

24. 교과활동 외에 다른 학생들과 의사소통이 원활하지 않아 학교생활 적응에 도움을 주고 싶은 학생을 만나신 적이 있으십니까?

1) 예 2) 아니오

24-1. 1)의 경우라면 어떤 도움이 필요하다고 생각하십니까?

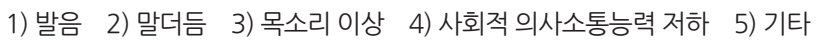

25. 일반학교에 특수교육대상자나 다문화가정, 중도입국가정, 북한이탈주민가정 학생이 증가하고 있습니다. 통합학급 담임을 맡게 된다면 기꺼이 맡으시겠습니까? 1) 예 2) 아니오 
25-1. 2) 아니오라면 그 이유는 무엇입니까?

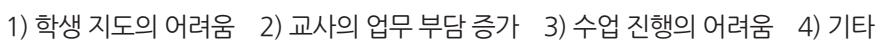

26. 통합학급에서 특수교육대상자나 다문화가정학생들을 위한 전문가 도움이 학생들의 교육적 성장에 필요하다고 생각되십니까?

1) 예 2) 아니오

27. 필요하다면 어떠한 도움을 지원하는 것이 바람직하다고 여기십니까?

$\begin{array}{lll}\text { 1) 의사소통 중심의 말언어지도 } & \text { 2) 맞춤형 언어치료지원 } & 3 \text { ) 교과과정 연계 언어치료 }\end{array}$

4) 수준별 교재교구 개발 5) 기타

28. 최근 왕따나 학교폭력 등 의사소통 교육부재로 인한 학교 부적응이 증가하고 있습니다. 입시위주의 경쟁과 코로나 19 이후로 개인간 의사소통이 줄어들어 있습니다. 학교에서 타인을 배려하고 소통하는 능력을 교육하는 것이 필요하다고 생각하십니까?

1) 예 2) 아니오

29. 사회적 의사소통 교육을 담당하는 전문가가 있다면 학생들의 학교생활과 학업에 도움이 된다고 생각하십니까?

1) 예 2) 아니오

30. 만약 '1) 예'라면 전문가를 통해 어떤 방식으로 사회적 의사소통교육을 하는 것이 바람직하다고 생각하십니까?

1) 교과과정을 통한 정기적인 지도 2) 교과외 지도 3 ) 문제아동 선별지도

4) 부모교육을 위한 가정통신문 배부 5) 기타 


\section{국문초록}

\section{학교언어재활사 제도에 대한 교사 인식 및 요구도 조사}

최성희 ${ }^{\prime} \cdot$ 이은경

${ }^{1}$ 대구가톨릭대학교 언어청각치료학과, ${ }^{2}$ 동신대학교 언어치료학과

배경 및 목적: 최근 학교 교실내에 다양한 학생 인구가 증가하면서 다양한 의사소통 문제에 대한 중재 필요성이 강조되고 있다. 본 연구 는 한국의 학교언어재활사 제도 의무배치에 대한 교사들의 인식과 요구도를 조사함으로써 학교언어재활사 제도의 입법 제안을 위한 기초자료로 제시하고자 한다. 방법: 구글설문지를 사용하여 유, 초, 중, 고등학교 교사들에게 학교언어재활사 의무배치에 대한 교사의 인식 및 요구도를 조사하였다. 총 141 명의 교사가 응답하였으며, 각 설문지의 응답은 엑셀을 이용하여 빈도수와 평균값을 계산하였다. 결과: 담당학생의 의사소통 문제 유형은 다문화가정 $37.3 \%$, 느린학습자 $33.3 \%$, 기타 의사소통 문제를 가진 아동 $27 \%$ 순으로 나타났다. 학생의 의사소통 어려움으로는 사회적 의사소통기술이 $40.6 \%$ 로 가장 많았고, 문해력 $22.7 \%$, 발음 $16.4 \%$, 어휘력 $9.4 \%$ 순이었다. 수업에 참여하는데 어려움이 있는 학생이 있다고 응답한 경우가 $80 \%$ 이상이었고, 이 중에서 수업 내용의 이해부분이 $73.9 \%$ 로 가장 많았으며, 교사의 지시따르기 $32.2 \%$, 수업 발표 $17.4 \%$ 에 대해 어려움을 보였다. 또한, 수업 참여의 어려움이 있는 학생으로 인한 피해 여부, 업무적 부담 등에 대해 과반수 이상이 ‘예’라고 응답하였다. 아울러, 학생들에게 도움을 줄 수 있는 전문가가 있다면 업무적 부담이 감소되고 학생들에게도 도움이 된다고 인식하는 교사가 $96.5 \%$ 에 달하였다. 전문가의 도움의 형태는 문제에 대한 맞춤형 지원 $75.9 \%$, 교과기반 지원 $17 \%$, 부모교육지원 $5.7 \%$ 순이었다. 또한, 교사의 $99.3 \%$ 는 학교에서 타인을 배려하고 소통하는 사회적 의사소통 능력을 교육하는 것이 필요하다고 응답하였다. 논의 및 결론: 교사들은 학교 현장에서 학교언어재활사 전문가 지원이 절실하다고 인식하였으며, 학교언 어재활사 의무배치는 교사뿐만 아니라, 학생 및 부모에게도 학교 교육이나 사회적 의사소통능력 향상에 도움이 될 수 있는 프로그램을 제공할 수 있을 것이다.

핵심어: 교사 인식, 교사 요구, 학교기반 언어재활 서비스, 학교언어재활사, 학교언어치료

\section{참고문헌}

교육통계서비스 (2019). 교육통계연보. 진천: 교육통계서비스.

교육부 (2020). 특수교육 통계연보. 세종: 교육부.

교육부 (2021). 제2차 인성교육 종합계획.

국립특수교육원 (2006). 치료교육의 실태 및 개선방안 연구. 아산: 국립특수교육원.

김수진, 최승수, 김정연 (2006). 특수학급 교사들의 학교 언어치료 서비스 모형에 관한 인식조사. 언어청각장애연구, 11(1), 121-139.

서미옥 (2020). 코로나 팬데믹 온라인 수업 사례로 본 교육대학원생들의 인식. 학습자중심교과교육학회지, 21(2), 561-582.

신명선 (2020). 학교 환경 언어치료 지원에 대한 초등 특수 교사의 인식. 언어치료연구, 29(2), 165-185.

양지희, 박성지 (2016). 학교 환경 언어치료의 운영 실태와 특수교사의 인식 조사: 충남지역을 중심으로. 특수교육재활과학연구, 55(3), 537-557.

전북지역교육연구소 (2021). 전북교육정책 온라인 설문조사.

최지은, 이윤경 (2016). 학교언어재활사의 실태와 직업만족도 연구. 언어치료연구, 25(2), 145-160.

황우아, 이은경 (2016). 전라남도 특수학급 언어치료지원 운영 실태와특수교사 인식. 언어치료연구, 25(1), 159-171.

\section{ORCID}

최성희(제1저자, 교수 https://orcid.org/0000-0003-2365-6187); 이은경(교신저자, 교수 https://orcid.org/0000-0003-2053-4248) 